\title{
Life cycle of Musculium lacustre (Bivalvia: Sphaeriidae) in the Saône river at Lyon (France) : a curious life strategy
}

\author{
J. Mouthon* \\ Cemagref, 3 bis quai Chauveau, CP 220, 69336 Lyon cedex 09, France.
}

\begin{abstract}
The life cycle of Musculium lacustre populations in the Saône river at Lyon was studied over a three-years period. Following the growth period which occurs from March to June, adults released larvae, then disappeared during the summer. Only a few newborn of the new generation that appeared in May and June grow and give birth to a second generation at the end of summer or in autumn. Most of the juveniles of the first generation estivate, then hibernate with those of the second generation until the following spring. The individuals of each generation only reproduce once (semelparity). Longevity of M. lacustre is from 13 to 14 months. In 2001, the spring flood disturbed the progress of the life cycle and delayed the appearance of the new generation for one month. In 2003, a large accumulation of dead leaves at the beginning of winter and high spring temperatures led to considerable production of larvae. However, this was not followed by an increase in numbers: high mortality among the newborn occurred during May and June. These observations suggest that $M$. lacustre populations of the Saône are habitually food-limited. Nonetheless, the life cycle strategy adopted by this bivalve enabled it to withstand the high summer temperatures of 2003 as opposed to other Sphaeriidae (Pisidium) which disappeared in August.
\end{abstract}

Keywords : Musculium lacustre, Mollusca, life history, growth, Saône River.

\section{Introduction}

Like all Sphaeriidae Musculium lacustre (Müller) is ovoviviparous. Its eggs, closed inside broodsacs, are incubated within the anterior, inner demibranches and up to three broodsacs can develop simultaneously (Okada 1935, Heard 1977). Consequently, each parent contains several ontogenetic larval stages. This holarctic species has been recorded in Europe, North America, the Far East, the Pacific area (Herrington 1962), and also in Africa where it is confined to the coastal Algerian Atlas (Van Damme 1984). It inhabits ponds, lakes, where it is found at a depth up to $12 \mathrm{~m}$ (Walter \& Kuiper 1978), and rivers, but it is more plentiful in stagnant than in running waters (Boycott 1936). In rivers, $M$. lacustre reaches its optimum (frequency and abundance) at the potamon (Mouthon 1999).

\footnotetext{
* Corresponding author :

E-mail: jacques.mouthon@Lyon.cemagref.fr
}

Up to day, the life cycles of only four populations of $M$. lacustre have been studied. The first came from a temporary pond in Russia (Mitropolskji 1965), the second and third from two permanent ponds in Canada (Mackie 1979), and the fourth from a drainage ditch in Hong-Kong, China (Morton 1985). The aim of this work is to describe the life cycle of a population of this bivalve from the lower reaches of a large river during a period of more than three years in a region with a temperate climate. The impact of environmental parameters on annual variations of its life-history strategy is also examined.

\section{Material and methods}

Musculium were collected monthly from December 2000 to April 2004 in the Saône upstream of the Ile Barbe located at the river's entry in the conurbation of Lyon (Fig. 1). At this point the river is approximately 150 meters wide, two thirds of this width being taken up by a navigable channel. The average slope of the 


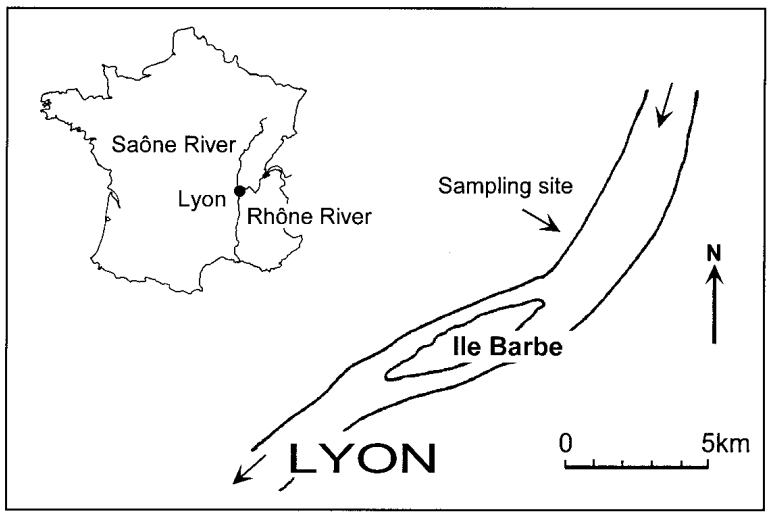

Fig. 1. Location of the clam sampling site in the Saône River at the Ile Barbe (Lyon).

Saône from the last lock to its confluence with the Rhone is $0.32 \mathrm{~m} / \mathrm{km}$. The collection site, located on the right bank, was approximately 150 meters in length. From May to October, more than half its surface area was invaded by different species of macrophytes : $\mathrm{Nu}$ phar, Ceratophyllum, Potamogeton and filamentous algae. Sampling was carried out at four stations at a depth from 0.50 to $1.5 \mathrm{~m}$ using a rectangular hand-net $(25 \times 18 \mathrm{~cm})$; the total surface area sampled was $1 \mathrm{~m}^{2}$. The samples were fixed on-site in $12 \%$ neutralised formaldehyde and sieved at $450 \mu \mathrm{m}$ in the laboratory.

The shell length (SL, greatest anterior-posterior di- mension across the valves) of individuals was measured with an eye piece micrometer at $25 \mathrm{x}$ (clams with $\mathrm{SL}<6.0 \mathrm{~mm}$ ) or $12.5 \mathrm{x}$ (clams with SL $>6.0 \mathrm{~mm}$ ) under a binocular microscope. The interval of the size frequency histograms was $0.5 \mathrm{~mm}$ size classes, they were then analysed using Bhattacharya's (1967) graphical method available in the FiSAT software distributed by FAO-ICLARM (Gayanilo et al. 1996). For each generation, the mean size of the individuals, the number and the standard deviation were established. All individuals with SL $>2.0 \mathrm{~mm}$ were dissected and all shelled larvae, i.e. prodissoconch and extra-marsupial larvae (Heard 1977), were measured and counted.

Discharge rates at Mâcon, situated $68 \mathrm{~km}$ upstream from the Ile Barbe and downstream of the Saône's main tributaries, were extracted from the HYDRO database. Water physico-chemical data were supplied by the Rhône, Mediterranean, Corsica Water Agency. During the study, the temperature of the water was recorded every week.

\section{Results}

\section{Environmental variables}

The Saône has a pluvial-oceanic type hydrological regime (Pardé 1925) with high flow in the winter and spring and low in summer (Fig. 2). Maximum water temperatures occurring in August ranged from $25.4^{\circ} \mathrm{C}$ in 2001 to $29^{\circ} \mathrm{C}$ in 2003 and $26^{\circ} \mathrm{C}$ in June 2002 . The

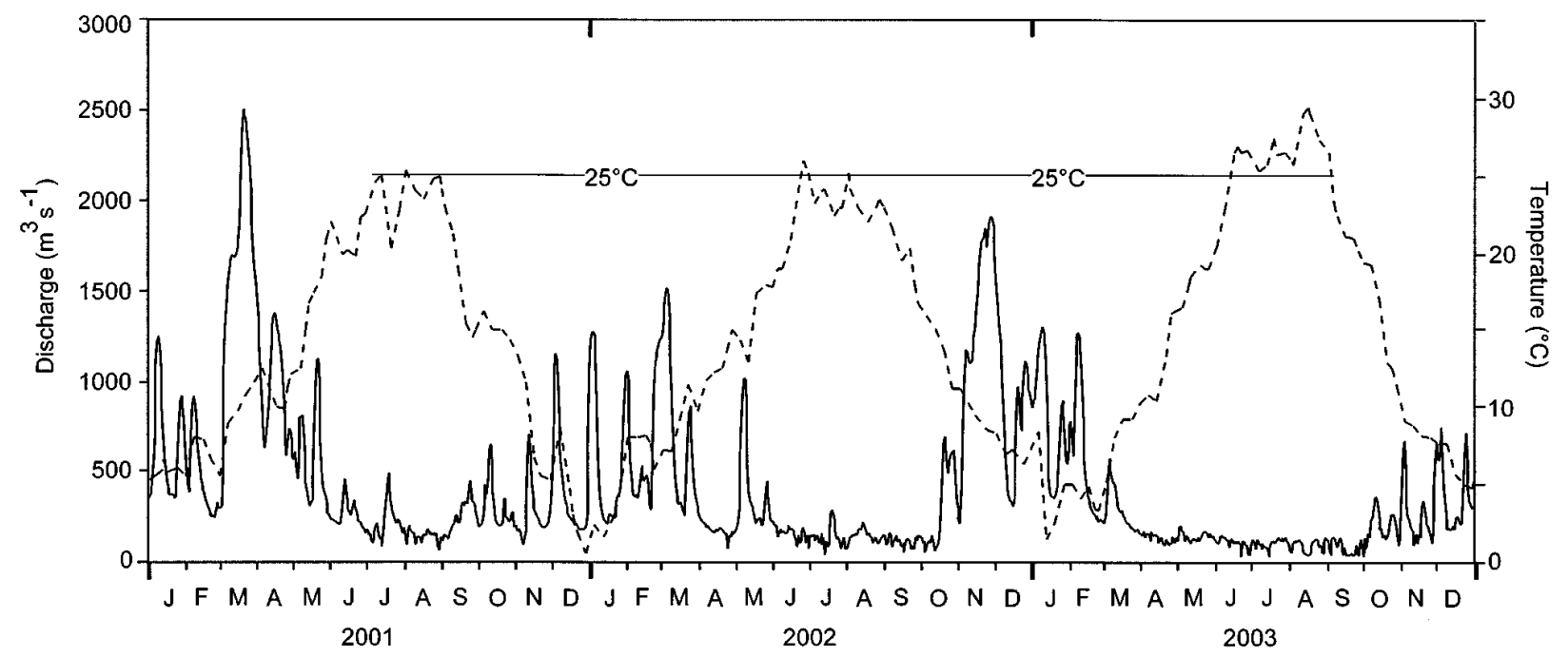

Fig. 2. Daily discharge rate at Mâcon (HYDRO database, bold lines) and weekly temperatures of the Saône River at the Ile Barbe (Lyon, dashed lines). 
Table 1. Water chemistry data at the Ile Barbe (Saône River). Mean, standard deviation, minima and maxima of variables are determined from monthly $(2001,2002)$ or ten analysis (2003) for the first eight variables, and from six values for the six other variables (RMC Water Agency data). Units are $\mu \mathrm{S} \mathrm{cm}^{-1}$ for conductivity and $\mathrm{mg} \mathrm{L}^{-1}$ for the other variables. DO : dissolved oxygen, DOC : dissolved organic carbon.

\begin{tabular}{|c|c|c|c|c|c|c|c|c|c|}
\hline & & pH & Cond & DO & DOC & $\mathrm{NH}_{4}^{+}$ & $\mathrm{NO}_{2}^{-}$ & $\mathrm{NO}_{3}^{-}$ & $\mathrm{PO}_{4}{ }^{3-}$ \\
\hline \multirow[t]{4}{*}{2001} & mean $(n=12)$ & 8 & 475.4 & 9.6 & 3.33 & 0.08 & 0.075 & 9.6 & 0.24 \\
\hline & S.D. & 0.26 & 53.7 & 1.64 & 1.0 & 0.03 & 0.03 & 1.94 & 0.08 \\
\hline & minimum & 7.2 & 363 & 7.3 & 2.2 & 0.01 & 0.05 & 6.2 & 0.18 \\
\hline & maximum & 8.2 & 547 & 12 & 5.8 & 0.13 & 0.14 & 13 & 0.42 \\
\hline \multirow[t]{4}{*}{2002} & mean $(n=12)$ & 8 & 505 & 9.5 & 3.1 & 0.09 & 0.08 & 8.5 & 0.18 \\
\hline & S.D. & 0.12 & 73.4 & 1.81 & 0.8 & 0.04 & 0.02 & 2.80 & 0.08 \\
\hline & minimum & 7.8 & 360 & 7.2 & 2.2 & 0.05 & 0.05 & 3.5 & 0.04 \\
\hline & maximum & 8.2 & 641 & 12.7 & 4.7 & 0.18 & 0.11 & 13 & 0.35 \\
\hline \multirow[t]{5}{*}{2003} & mean $(n=10)$ & 8 & 581 & 8.8 & 2.8 & 0.14 & 0.09 & 7.6 & 0.18 \\
\hline & S.D. & 0.30 & 127.8 & 2.37 & 1.0 & 0.05 & 0.02 & 6.3 & 0.10 \\
\hline & minimum & 7.3 & 428 & 5.4 & 0.7 & 0.06 & 0.06 & 1 & 0.06 \\
\hline & maximum & 8.3 & 853 & 11.7 & 3.9 & 0.22 & 0.12 & 21 & 0.32 \\
\hline & & $\mathrm{HCO}_{3}^{-}$ & $\mathrm{Cl}^{-}$ & $\mathrm{SO}_{4}^{-}$ & $\mathrm{Ca}^{+}$ & $\mathbf{M g}^{++}$ & $\mathrm{Na}^{++}$ & & \\
\hline \multirow[t]{4}{*}{$2001-2003$} & mean $(n=8)$ & 212.7 & 41.3 & 31.1 & 76.0 & 3.9 & 24.7 & & \\
\hline & S.D. & 32.1 & 32.0 & 15.6 & 10.8 & 0.7 & 19.3 & & \\
\hline & minimum & 178 & 10.6 & 13.4 & 62 & 3.2 & 6.5 & & \\
\hline & maximum & 247 & 96 & 48 & 91 & 5 & 55 & & \\
\hline
\end{tabular}

year 2003 was characterised by a considerable water shortage with an average annual flow of only $261 \mathrm{~m}^{3} \mathrm{~s}^{-1}$ v.s. 524 and $466 \mathrm{~m}^{3} \mathrm{~s}^{-1}$, respectively in 2001 and 2002 . Temperatures were higher than $25^{\circ} \mathrm{C}$ from mid-June to the end of August.

The water of the Saône at the Ile Barbe is alkaline, rich in inorganic elements, such as calcium, and generally well oxygenated: minima did not fall below 7.2 $\mathrm{mg} \mathrm{L}^{-1}$ in 2001 and 2002, though in 2003, concentrations in dissolved oxygen were less than $7 \mathrm{mg} \mathrm{L}^{-1}$ from June to September and minimal in August $\left(5.4 \mathrm{mg} \mathrm{L}^{-1}\right)$ (Table 1). In spite of the dilution provided by the water of the river Doubs, the Saône's main tributary, the chlorine and sodium concentrations stemming from the industrial wastes of the Solvay factories remain high. Concentrations of $\mathrm{NO}_{2}^{-}, \mathrm{NH}_{4}{ }^{+}$and $\mathrm{PO}_{4}{ }^{3-}$ reveal low to moderate biodegradable pollution due to human activities.

\section{Life cycle}

At the beginning of the year, a single cohort was represented and the minimum size of individuals was 1 mm (Fig. 3A). In 2001, 2003 and 2004, growth started in March but in 2002 it started earlier and began in February (increase of the standard deviation). In May 2001, the cohort born the previous year reached an average size of $5.2 \mathrm{~mm}$. Large individuals $(>8.5 \mathrm{~mm})$ subsisted rarely until July. At the end of the growth period, lasting from four to five months, the cohorts that appeared in 2001 and 2002 reached an average size of respectively 6.25 and $7.33 \mathrm{~mm}$ in June 2002 and 2003. However, these two cohorts were no longer present in July.

In 2002 and 2003, the number of gravid individuals and shelled larvae peaked in May (Fig. 3B) and juveniles released during the same month give birth to a new cohort (Fig. 3A). On the other hand, in 2001, the new cohort did not appear until June and the low number of larvae released did not reach its maximum until July. In June 2001 and May 2002, some newborn individuals started their growth but this stopped suddenly since they were not found the following month. However, in 2003, individuals born in May continued their growth. In July, they reached an average size of 5.25 
$\mathrm{mm}$ and then disappeared. In June, a second generation appeared whose average size $(1 \mathrm{~mm})$ did not vary until February 2004 (Fig. 3A).

Outside the incubation period, which generally culminates in May-June or July, certain gravid individuals were observed in November, December 2001 and January 2002, August and September 2002, and from January to March 2003 (Fig. 3B). Nonetheless, the maximum size of these bivalves $(<6.5 \mathrm{~mm})$ was clearly lower than that of the adults found in June-July 2001 or in May-June 2003 (>8.5 mm). However, no adults were observed from August 2003 to February 2004.

The number of larvae per parent varied considerably from year to year (Fig. 4). Peaks occurred in spring 2002 and 2003 and in summer 2001. In the Sphaeriidae, the number of larvae incubated is proportional to the size of the parents (Ladle \& Baron 1969, Meier-
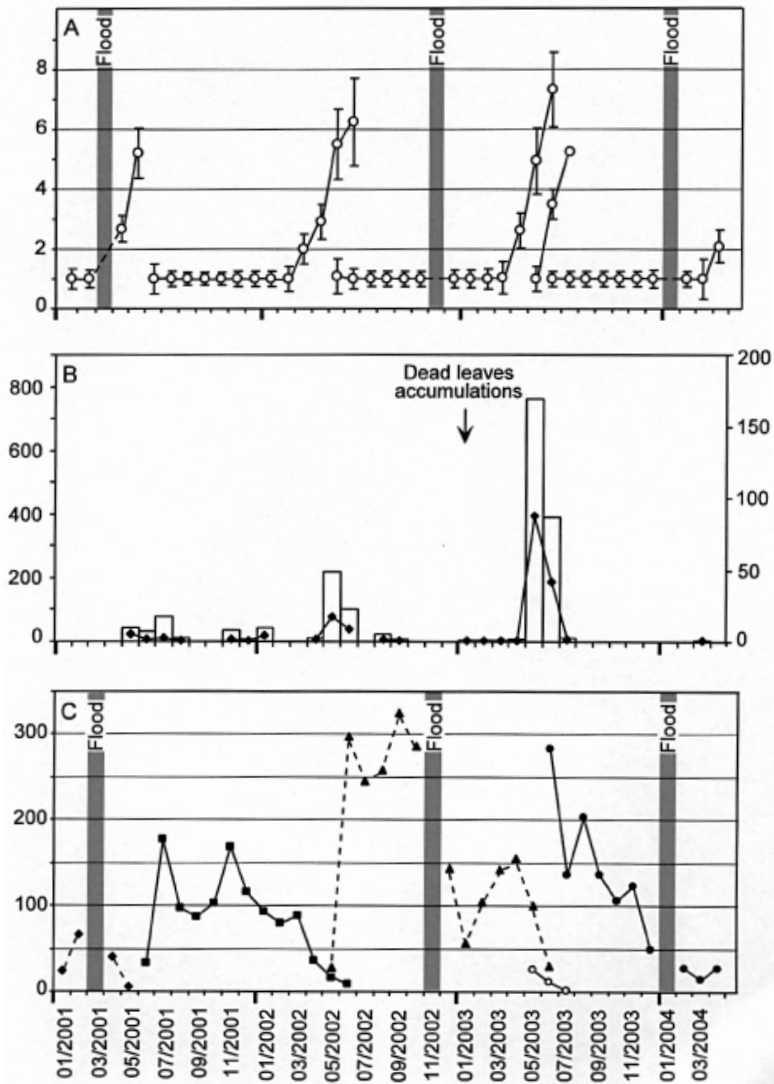

Fig. 3 (A): Mean cohort shell lengths (open circles) in monthly samples of the Ile Barbe (Saône River) Musculium lacustre population. Vertical bars are standard deviations. Grey strips indicate flood periods when sampling was not possible, (B): number of adults carrying shelled larvae (left vertical axis, vertical bars) and number of shelled larvae incubated (right vertical axis, bold lines); (C): density seasonal variations of cohorts.
Brook 1970, Heard 1977, Morton 1985, Holopainen 1979). As a result when the adults are only represented by large individuals, the litter size is very high as in July 2001. The largest individual was found during this month. It measured $9.85 \mathrm{~mm}$ and incubated 44 larvae: its last two broodsacs contained 19 and 25, respectively. However, the largest extra-marsupial larvae, ( $\mathrm{SL}=1.56 \mathrm{~mm}$ ) observed in June 2003, came from an individual that measured only $6.72 \mathrm{~mm}$.

When the generations of 2001 and 2002 appeared in June and May, respectively; they were only represented by a small number of individuals (Fig. 3C). An initial peak of abundance was observed the following month. The peaks of July 2001 and June 2002 occurred following a first release period. On the contrary, the peaks of November (2001 generation), September and April (2002 generation) corresponded to the periods described above during which gravid individuals were observed. This concordance suggests that these adults released larvae; two spawning periods therefore took place in 2001 and 2002. In 2003, two generations were represented but the numbers of the first were very low compared with those of the second whose abundance was maximal in June. However, the peak density that occurred in August suggests that larvae were released by adults of the first generation: two spawning periods very close together also occurred in 2003. At the beginning of the year, the populations were therefore represented by both juveniles of the first and the second generations.

The life cycle of the Musculium lacustre populations of the Saône is characterised by: 1- a growth period from March (February) to June followed, after the release of larvae, by the disappearance of adults during summer; 2- two birth periods producing two generations: the first appeared in May or June, while the second, more variable and smaller, appeared at the end of summer or in autumn; each generation only reproduces once (semelparity); 3 - juveniles that estivate and hi-

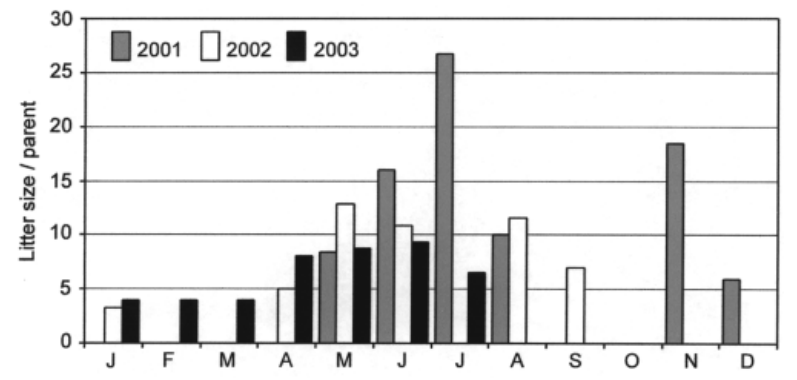

Fig. 4. Seasonal and annual variations in the litter size (the number of shelled larvae) per parent. 


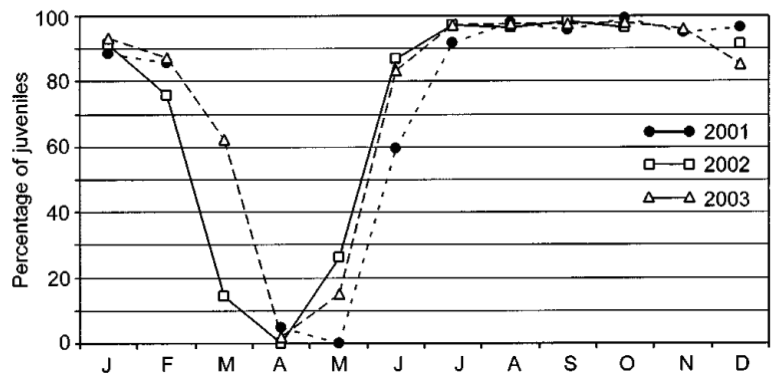

Fig. 5. Seasonal and annual variations in the percentages of juveniles (individuals with $\mathrm{SL}<1.51 \mathrm{~mm}$ ).

bernate represent more than $90 \%$ of the total number for more than half the year (Fig. 5); 4- longevity is 13 to 14 months in the region.

\section{Discussion}

In 2001, the appearance of the new generation and the peak of juveniles occurred later than in 2002 and 2003. The flood occurring in March, i.e. at the beginning of the growth period, was certainly responsible for the delay observed in the progression of the life cycle of M. lacustre. After the flood of November 2002, large quantities of dead leaves reaching thicknesses of more than $50 \mathrm{~cm}$ accumulated over a large part of the station. Since flows remained moderate during winter 2003, these accumulations of dead leaves decayed in situ; by April they had disappeared. Correlatively and contrary to the two previous years, gravid individuals appeared as early as January 2003, and in April the number of bivalves was three times higher than in January. Musculium's affinity for organic matter and the litter of dead leaves has been highlighted by several authors (Boycott 1936, Mackie et al. 1976, Morton 1985). This important trophic contribution and the average temperatures of May and June 2003 exceeding those of 2002 by 2.6 and $3.1^{\circ} \mathrm{C}$, respectively, favoured the growth of indivuals and their embryos (Holopainen \& Jonasson 1983). However, in spite of the large quantity of larvae incubated, this was not followed by a greater increase of numbers in June 2003 than in 2002 : considerable mortality in the newborn therefore took place during this month. In May and June 2003, concentrations in dissolved $\mathrm{O}_{2}$ of respectively 8.3 and $6.7 \mathrm{mg} \mathrm{L}^{-1}$ did not appear to be inhibiting for this species capable of withstanding periods of anoxia (Morton 1985) and considered as tolerant to biodegradable pollution (Mouthon 1996). Furthermore, temperatures $>25^{\circ} \mathrm{C}$ were only recorded from mid-June, i.e. only 6 days before the sampling campaign. These observations suggest that the lack of available food could be the main cause of this mortality and that the Musculium lacustre populations of the Saône are food-limited.

Several differences were identified in the characteristics of the life cycle of the populations studied. 1- In Hong-Kong, due to a hot and humid climate, the newborn of the first generation begin appearing in April (Morton 1985), in May and June in the Saône, and during June in Canada (Mackie 1979), whereas they do not appear until the beginning of July in Russia, after filling of the pond with water (Mitropolskji 1965). 2The minimum size of adults incubating shelled larvae is higher in the Chinese population $(8 \mathrm{~mm})$ than in those of Canadian ponds $(2.5-4.5 \mathrm{~mm})$ and the Saône (2.5 - $3.0 \mathrm{~mm})$. 3- The longevity of M. lacustre in China and Canada is estimated at 12 months (Mackie 1979, Morton 1985); however, it reached 13 to 14 months in the Saône. 3- The number of spring newborn growing to parental size and the numbers of the second generation to which they give birth are high in the Chinese and Canadian populations while they remain very low in the Saône (Mackie 1979, Morton 1985).

However, although the capacity of the newborn to estivate and hibernate is also observed in other species of Musculium, such as M. transversum (Gale 1977), M. securis (Mackie et al. 1976) and M. partumeium (Way et al. 1980), and it is considered as an adaptation in ephemeral habitats (Mackie et al. 1976, Way et al. 1980), the life cycle of $M$. lacustre takes place in a similar manner whether in drainage ditches, permanent and temporary ponds or large rivers. Furthermore, there is a considerable similarity between the life cycle of M. lacustre of the Saône in 2003 and that of M. securis and M. partumeium of temporary ponds (Mackie et al. 1976, Way et al. 1980). Indeed, M. lacustre's response to particularly high summer temperatures $\left(>25^{\circ} \mathrm{C}\right)$, i.e. 'dormancy' (no growth) of all the newborn from June to December, resembles the one observed in populations of $M$. securis and $M$. partumeium during the temporary drying of their habitat. This capacity of juveniles to estivate has permitted this bivalve to maintain its numbers in spite of the heat wave, whereas the other species of Sphaeriidae (Pisidium) completely disappeared during August. Undoubtedly, originally adapted to temporary environments, the Musculium lacustre populations that inhabit permanent habitats and large rivers have nonetheless conserved genetically controlled ancestral biological traits. As climate warming continues, the life-history strategy adopted by this bivalve could permit it to become the dominant 
sphaeriid species in the lower reaches of large rivers, as it is the case at present in the Saône upstream of Lyon.

\section{Acknowledgements}

I thank O. Fontaine (Rhône, Mediterranean, Corsica Water Agency) for physico-chemical data.

\section{References}

Bhattacharya C.G. 1967. - A simple method of resolution of a distribution into Gaussian components. Biometrics, 23, 115-135.

Boycott A.E. 1936. - The habitats of the freshwater Mollusca in Britain. J. Anim. Ecol., 5, 116-186.

Gale W.F. 1977. - Growth of the fingernail clam, Sphaerium transversum (Say) in field and laboratory experiments. The Nautilus, 91, 8-12.

Gayanilo F.C., Sparre P. \& Pauly D. 1996. - FAO-ICLARM stock assessment tools. Food and Agriculture Organization of the United Nations, Rome, Computed information series 8, pp. 1-126.

Heard W.H. 1977. - Reproduction of fingernail clams (Sphaeriidae: Sphaerium and Musculium). Malacologia, 16, 421-455.

Herrington H.B. 1962. - A revision of the Sphaeriidae of North America (Mollusca: Pelecypoda). Misc. Publ. Mus. Zool. Univ. Michigan, 118, 1-74.

Holopainen I.J. 1979. - Population dynamics and production of Pisidium species (Bivalvia, Sphaeriidae) in the oligotrophic and mesohumic lake Pääjärvi, southern Finland. Arch. Hydrobiol., 54, 466-508.

Holopainen I.J. \& Jonasson P.M. 1983. - Long-term population dynamics and production of Pisidium (Bivalvia) in the profundal of Lake Esrom, Denmark. Oikos, 41, 99-117.

Ladle M. \& Baron F. 1969. - Studies on three species of Pisidium (Mollusca: Bivalvia) from a chalk stream. J. Anim. Ecol., 38, 407413.

Mackie G.L. 1979. - Growth dynamics in natural populations of Sphaeriidae clams (Sphaerium, Musculium, Pisidium). Can. J. Zool., 57, 441-456.
Mackie G.L., Qadri S.U. \& Clarke A.H. 1976. - Intraspecific variations in growth, birth periods, and longevity of Musculium securis (Bivalvia: Spheriidae) near Ottawa, Canada. Malacologia, 15, 433-446.

Meier-Brook C. 1970. - Untersuchungen zur Biologie einiger Pisidium-Arten (Mollusca; Eulamellibranchiata; Sphaeriidae). Arch. Hydrobiol. Suppl., 38, 73-150.

Mitropolskji W.I. 1965. - Observations on the life cycle, growth rate and tolerance of drying in Musculium lacustre (Müller) (Lamellibranchiata). Trudy Inst. Biol. Vnutrennikh Vod, 8, 118-124 (in russian, not seen; cited by Heard 1997).

Morton B. 1985. - The populations dynamics, reproductive strategy and life history tactics of Musculium lacustre (Bivalvia: Pisidiidae) in Hong Kong. J. Zool. Lond., 207, 581-603.

Mouthon J. 1996. - Molluscs and biodegradable pollution in rivers: proposal for a scale of sensitivity of species. Hydrobiologia, 317, 221-229.

Mouthon J. 1999. - Longitudinal organisation of the mollusc species in a theoretical French river. Hydrobiologia, 390, 117-128.

Okada K. 1935. - Some notes on Musculium heterodon (Pilsbry), a freshwater bivalve. II. The gill, the breeding habits and the marsupial sac. Sci. Tôhoku Univ. Ser. 4, 9, 375-391.

Pardé M. 1925. - Le régime du Rhône. Etude hydrologique, Lyon (étude et travaux de l'I.E.R) Thèse Lettres, Grenoble, vol. 1 \& 2 : $883+440$ pp.

Van Damme D. 1984. - The freshwater Mollusca of northern Africa. Distribution, biogeography and palaeoecology. Dr. W. Junk Publishers, Dordrecht, $164 \mathrm{pp}$.

Way C.M., Hornbach D.J. \& Burky A.L. 1980. - Comparative life history tactics of the sphaeriid clam, Musculium partumeium (Say), from a permanent and temporary ponds. Am. Midl. Natur. 104, 319-327.

Walter J.E. \& Kuiper J.G.J. 1978. - Über Verbreitung und Ökologie von Sphaeriiden im Zürichsee (Mollusca : Eulamellibranchiata). Schweiz. Z. Hydrol., 40, 60-86. 